\title{
Presence of Borrelia miyamotoi infection in a highly endemic area of Lyme disease
}

Luis A. Marcos ${ }^{1,2^{*}}$, Kalie Smith ${ }^{1}$, Kelsey Reardon ${ }^{1}$, Fredric Weinbaum ${ }^{3}$ and Eric D. Spitzer ${ }^{4}$

\begin{abstract}
A series of cases in the Northeast of the US during 2013-2015 described a new Borrelia species, Borrelia miyamotoi, which is transmitted by the same tick species that transmits Lyme disease and causes a relapsing fever-like illness. The geographic expansion of B. miyamotoi in the US also extends to other Lyme endemic areas such as the Midwestern US. Co-infections with other tick borne diseases (TBD) may contribute to the severity of the disease. On Long Island, NY, 3-5\% of ticks are infected by B. miyamotoi, but little is known about the frequency of B. miyamotoi infections in humans in this particular region. The aim of this study was to perform a chart review in all patients diagnosed with B. miyamotoi infection in Stony Brook Medicine (SBM) system to describe the clinical and epidemiological features of B. miyamotoi infection in Suffolk County, NY. In a 5 year time period (2013-2017), a total of 28 cases were positive for either IgG EIA $(n=19)$ or PCR $(n=9)$. All 9 PCR-positive cases (median age: 67; range: $22-90$ years) had clinical findings suggestive of acute or relapsing infection. All these patients were thought to have a TBD, prompting the healthcare provider to order the TBD panel which includes a B. miyamotoi PCR test. In conclusion, B. miyamotoi infection should be considered in the differential diagnosis for flu-like syndromes during the summer after a deer tick bite and to prevent labeling a case with Lyme disease.
\end{abstract}

Keywords: Borrelia miyamotoi, Lyme disease, Tick borne diseases, New York

\section{Background}

Suffolk County, a suburban county on Long Island (LI), New York, has a population of 1.8 million people and annually reports the highest absolute number of tickborne diseases in NY. In 2017, there were 523 cases of Lyme disease, 55 cases of Ehrlichiosis, 31 cases of Anaplasmosis, and 138 cases of Babesiosis [1]. A series of cases in the Northeast US described a new Borrelia species, Borrelia miyamotoi, first reported to cause human infections in 2013 [2]. B. miyamotoi is closely related to the relapsing fever family of Borrelia spp (e.g. B. hermsii); however, it is transmitted by Ixodes scapularis, the same tick that transmits Borrelia burgdorferi (Lyme disease), Anaplasma phagocytophilum and Babesia microti [3].

*Correspondence: luis.marcos@stonybrookmedicine.edu

${ }^{1}$ Division of Infectious Diseases, Department of Internal Medicine, Stony Brook University, 101 Nicolls Rd, HSC16-027 J, Stony Brook, NY 11794, USA

Full list of author information is available at the end of the article
The geographic expansion of $B$. miyamotoi in the US extends to other Lyme endemic areas such as the Midwest of North America [4]. B. miyamotoi infection can clinically present during warm months as a flu-like syndrome similar to Lyme disease, Anaplasmosis, or Babesiosis. The diagnosis of $B$. miyamoto $i$ infection is complicated by the overlap in clinical manifestations caused by other TBD and the need to order specific diagnostic tests that may not be familiar to general practitioners even in hyperendemic areas for TBD such as LI [5]. In addition, little is known about co-infections between $B$. miyamotoi and the other TBD. Although 3-5\% of ticks on LI have been found to be infected by B. miyamotoi and up to $74 \%$ have B. burgdorferi [6], there is no evidence that co-infections have occurred in humans who have been diagnosed with early Lyme disease in New York [7]. The goal of this study was to describe the recent epidemiology of $B$. miyamoto $i$ by performing a retrospective chart review in all patients

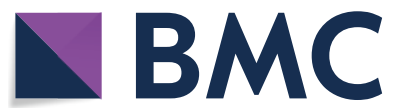

(c) The Author(s) 2020. This article is licensed under a Creative Commons Attribution 4.0 International License, which permits use, sharing, adaptation, distribution and reproduction in any medium or format, as long as you give appropriate credit to the original author(s) and the source, provide a link to the Creative Commons licence, and indicate if changes were made. The images or other third party material in this article are included in the article's Creative Commons licence, unless indicated otherwise in a credit line to the material. If material is not included in the article's Creative Commons licence and your intended use is not permitted by statutory regulation or exceeds the permitted use, you will need to obtain permission directly from the copyright holder. To view a copy of this licence, visit http://creativeco mmons.org/licenses/by/4.0/. The Creative Commons Public Domain Dedication waiver (http://creativecommons.org/publicdomain/ zero/1.0/) applies to the data made available in this article, unless otherwise stated in a credit line to the data. 
diagnosed with B. miyamotoi infection in Stony Brook Medicine (SBM) system, Suffolk County, NY.

\section{Methods}

A retrospective study was conducted at Stony Brook Medicine (SBM) Hospitals (Stony Brook University Hospital-SBUH- and Southampton Hospital-SHH) between January 1, 2013 and December 31, 2017. SBM is the only tertiary medical center in Suffolk County, NY. The case search was performed from only positive tests results from the laboratory database. A positive result for $B$. miyamotoi was determined by either a positive real-time qPCR in the blood or IgG antibody detected by EIA using B. miyamotoi glycerophosphodiester phosphodiesterase recombinant antigen (rGlpQ) using previously described assays $[8,9]$ (performed at Oxford Immunotec, Norwood, MA).

\section{Results}

At $\mathrm{SHH}$, a total of 8575 PCR tests were performed for both $B$. burgdorferi and for B. miyamotoi, with positive results for $19(0.2 \%)$ and $17(0.19 \%)$ of these organisms, respectively. Other TBD results were; Babesia PCR in blood was $1.5 \%(263 / 17,626)$, A. phagocytophilum was $0.4 \%$ (80/17501), and Ehrlichia chaffeensis was 1\% $(172 / 16955)$. At SBUH, less than 200 PCR and IgG EIA tests for B. miyamotoi were performed during the study period. All PCR tests were negative at SBUH. For IgG EIA, 8 were positive at $\mathrm{SHH}$ (total tested $=38$ ) and 11 were positive at SBUH (total tested $=60$ ). A total of 28 cases were positive for either IgG EIA $(n=19)$ or PCR $(n=9)$ (8 other PCR-positive cases were not included because clinical information was not available).

All 9 PCR-positive cases (median age: 67; range: 22-90 years) had clinical findings suggestive of acute or relapsing infection. Of these 9 cases, 8 were men (88\%), 3 were diagnosed in the outpatient clinic (33.3\%), while the remaining 6 (66.6\%) were diagnosed through the emergency room and required hospitalization. Demographics, clinical manifestations, and laboratory results on patients who had a positive blood B. miyamotoi PCR test are described in Table 1. None of these 9 cases had evidence for active co-infections with other TBD (all had negative blood PCR results for Ehrlichia, Anaplasma, Babesia, and Borrelia burgdorferi). One case had a positive IgM for Lyme with band 41 present in immunoblot but no erythema migrans, and another case had a positive IgG for B. burdogferi with 10 bands in the immunoblot.

Table 1 Demographics, clinical manifestations and laboratory results on patients with Borrelia miyamotoi PCR positive in the blood

\begin{tabular}{|c|c|c|c|c|c|c|c|c|c|}
\hline \multirow[t]{2}{*}{ Case } & \multirow{2}{*}{$\begin{array}{l}\text { Age } \\
\text { Gender }\end{array}$} & \multirow[t]{2}{*}{ Co-infections } & \multirow{2}{*}{$\begin{array}{l}\text { Clinical } \\
\text { manifestations }\end{array}$} & \multicolumn{6}{|l|}{ Laboratory findings } \\
\hline & & & & $\mathrm{WBC}\left(/ \mathrm{mm}^{3}\right)$ & $\mathrm{Hb}(\mathrm{g} / \mathrm{dL})$ & $\begin{array}{l}\text { Platelets (/ } \\
\left.\mathrm{mm}^{3}\right)\end{array}$ & $\begin{array}{l}\text { Creatinine (mg/ } \\
\mathrm{dL})\end{array}$ & AST (IU/L) & $\overline{A L T}($ IU/L) \\
\hline 1 & $90 / \mathrm{M}$ & Negative & $\begin{array}{l}\text { Fatigue, vomiting, } \\
\text { fevers }\end{array}$ & $4100(90 \% N)$ & 9.7 & 91,000 & 1.46 & 74 & 46 \\
\hline 2 & $22 / \mathrm{M}$ & Negative & $\begin{array}{l}\text { Headaches, fevers, } \\
\text { abdominal pain, } \\
\text { arthralgia }\end{array}$ & $3200(88 \%$ N) & 14.7 & 99,000 & 0.8 & 73 & 117 \\
\hline 3 & $26 / M$ & Negative & $\begin{array}{l}\text { Fevers, diarrhea, } \\
\text { hematuria }\end{array}$ & $5400(40 \% \mathrm{~N}, 30 \% \mathrm{~B})$ & 16.3 & 127,000 & 1.05 & 51 & 68 \\
\hline 4 & $74 / \mathrm{M}$ & Negative & Fatigue, arthralgia & $4600(63 \% \mathrm{~N})$ & 14.2 & 154,000 & 0.7 & 21 & 28 \\
\hline 5 & $32 / \mathrm{M}$ & Negative & $\begin{array}{c}\text { Fevers, muscle } \\
\text { pain, fatigue }\end{array}$ & $3000(45 \% N, 9 \% B)$ & 15.6 & 166,000 & 1.0 & 98 & 65 \\
\hline 6 & $74 / \mathrm{M}$ & Negative & $\begin{array}{l}\text { Fevers, myalgia, } \\
\text { chills, vomiting }\end{array}$ & 6800 (N37\%, B17\%) & 15.6 & 51,000 & 3.1 & 212 & 165 \\
\hline 7 & $68 / \mathrm{M}$ & Negative & $\begin{array}{l}\text { Fever, myalgia, } \\
\text { arthralgia, fatigue }\end{array}$ & Unknown & Unknown & Unknown & Unknown & 20 & 18 \\
\hline 8 & $67 / F$ & Negative & $\begin{array}{l}\text { Fevers, arthralgias, } \\
\text { mylagias }\end{array}$ & 5500 (N 64\%) & 14.7 & 260,000 & 0.8 & 33 & 23 \\
\hline 9 & $60 / M$ & Unknown & $\begin{array}{l}\text { Unknown Fevers, } \\
\text { arthralgia, myal- } \\
\text { gias, fatigue }\end{array}$ & 7100 (N 60\%) & 14.8 & Unknown & Unknown & Unknown & Unknown \\
\hline
\end{tabular}

Case 1-6 were hospitalized. Case 7-9 were diagnosed in the outpatient clinic. All patients received doxycycline $100 \mathrm{mg}$ orally for $14-21$ days. Co-infections negative: Babesia, anaplasma and Ehrlichia PCR in blood were negative. Case 1: procalcitonin $0.19 \mathrm{ng} / \mathrm{mL}$. Case 2: CSF analysis showed $14 \mathrm{WBC}$ (86\% L), Glucose $69 \mathrm{mg} / \mathrm{dL}$, Protein 22 mg/dL Normal values: WBC (4800-10,800/mm3), Hb (12-16 g/dL), platelets (150,000-450,000/mm3), creatinine (less than 1.2 mg/dL), AST (less than 32 IU/L) and ALT (less than $33 \mathrm{IU} / \mathrm{L}$ )

ARF Acute renal failure, $C R P C$-reactive protein, $W B C$ White blood cells, $N$ Neutrophils, $B$ bands, $M$ monocytes, $L$ Lymphocytes, $H b$ Hemoglobin, $A S T$ aspartate aminotransferase, $A L T$ Alanine aminotransferase 


\section{Discussion and conclusions}

The positivity rate of $B$. miyamotoi $\mathrm{PCR}$ in this area of $\mathrm{NY}$ in a 5-year study period is $0.19 \%(17 / 8575)$. We were able to review clinical records for 9 of these PCR positive cases. B. miyamotoi PCR was ordered in these patients at $\mathrm{SHH}$ was because they had clinical manifestations compatible with a TBD in the summer and this PCR test is part of a TBD panel offered by a commercial laboratory. In contrast, at $\mathrm{SBUH}$, diagnostic tests for $B$. miyamoto (PCR and/or EIA) were rarely performed, most likely because the commercial TBD panel was not included in the routine test catalog; most of these tests were ordered as part of Infectious Disease service consultations, based on specific clinical findings.

It is possible that most of the patients in this study were thought to have Lyme disease after a deer tick bite, prompting the healthcare provider to order the TBD panel which includes a $B$. miyamotoi PCR test. One $B$. miyamotoi PCR positive case had a positive IgM for Lyme with the band 41 positive, which is not a serological criterion for acute Lyme. The presentation of this case was not consistent with acute Lyme, but with the other tick-borne disease such as Ehrlichia, Anaplasma or B. miyamotoi infection (leukopenia, transaminitis, thrombocytopenia). The true incidence of B. miyamotoi on LI is unknown; however, when compared to other TBD tested in the same healthcare system, the percentage of positive tests for B. miyamotoi was similar to that of other TBD present in this region. Lack of knowledge about laboratory tests for B. miyamotoi may hinder its detection. Whereas most clinicians are aware of the two-tiered algorithm for Lyme serology (despite its relatively poor sensitivity) [10], many clinicians are not aware that PCR performed on blood is the optimal test for detecting acute $B$. miyamotoi infection or that serologic diagnosis requires the use of rGlpQ-based EIA (the GlpQ protein is present in the relapsing fever group of Borrelia spp, but is not found in B. burgdorferi). B. miyamotoi infection often produces a positive result on a whole-cell lysate Lyme EIA or the Lyme C6 peptide antibody test [11, 12], but in most cases the Lyme immunoblot is negative, a result that is also common in early Lyme disease. Based on the partial cross-reactivity between B. burgdorferi and B. miyamotoi, a negative result on a Lyme serology assay does not rule out $B$. miyamotoi infection.

Limitations of this study include the retrospective nature and lack of convalescent titers in some patients. However, this study may serve first as a baseline to consider B. miyamotoi infection in some flu-like syndromes during the summer after a deer tick bite and second, to avoid misidentifying a case as early Lyme disease when in fact it could be a B. miyamotoi infection whose long-term symptoms may be similar to post-Lyme disease syndrome
(PLDS) [13]. Whether some of the PLDS cases reported in clinical practice may have been related to $B$. miyamoto $i$ infections or other TBD remains an open question.

\section{Abbreviations \\ LI: Long island; PLDS: post-Lyme disease syndrome; SBM: Stony brook medi- cine; SBUH: Stony Brook University Hospital; SHH: Southampton Hospital; TBD: Tick borne disease(s).}

\section{Acknowledgements}

We thank Dr. Phillip Molloy for providing information about the total number of tests positive for TBD performed at SHH.

\section{Authors' contributions}

LAM, KS, ES designed the study. KS and LAM did the chart review. LAM wrote the first draft of the manuscript. LAM, KS, KR, FW, EDS reviewed and edited the final manuscript. All authors read and approved the final manuscript.

\section{Funding}

None.

\section{Availability of data and materials}

All data generated or analyzed during this study are included in this published article.

Ethics approval and consent to participate

This study was approved by the Stony Brook University Institutional Review Board (IRB) (IRB\# 834409).

\section{Competing interests}

The authors declare that they have no competing interests.

\section{Author details}

${ }^{1}$ Division of Infectious Diseases, Department of Internal Medicine, Stony Brook University, 101 Nicolls Rd, HSC16-027 J, Stony Brook, NY 11794, USA.

${ }^{2}$ Department of Microbiology and Immunology, Stony Brook University, Stony Brook, NY, USA. ${ }^{3}$ Stony Brook Southampton Hospital, Southampton, NY, USA.

${ }^{4}$ Department of Pathology, Stony Brook University, Stony Brook, NY, USA.

Received: 12 February 2020 Accepted: 19 May 2020

Published online: 30 May 2020

\section{References}

1. Department of Health, New York State. 2017. https://www.health.ny.gov/ statistics/diseases/communicable/2017/docs/cases.pdf.

2. Krause PJ, Narasimhan S, Wormser GP, Rollend L, Fikrig E, Lepore T, Barbour A, Fish D. Human Borrelia miyamotoi infection in the United States. N Engl J Med. 2013;368(3):291-3.

3. Krause PJ, Fish D, Narasimhan S, Barbour AG. Borrelia miyamotoi infection in nature and in humans. Clin Microbiol Infect. 2015;21(7):631-9. https:// doi.org/10.1016/j.cmi.2015.02.006

4. Jobe DA, Lovrich SD, Oldenburg DG, Kowalski TJ, Callister SM. Borrelia miyamotoi infection in patients from upper midwestern United States, 2014-2015. Emerg Infect Dis. 2016;22(8):1471-3. https://doi.org/10.3201/ eid2208.151878.

5. Karan $\mathrm{L}$, et al. Dynamics of spirochetemia and early PCR detection of Borrelia miyamotoi. Emerg Infect Dis. 2018;24:860-7. https://doi.org/10.3201/ eid2405.170829.

6. Sanchez-Vicente S, Tagliafierro T, Coleman JL, Benach JL, Tokarz R. Polymicrobial Nature of Tick-Borne Diseases. MBio. 2019;10(5):e02055. https:// doi.org/10.1128/mbio.02055-19.

7. Wormser GP, McKenna D, Scavarda C, Cooper D, El Khoury MY, Nowakowski J, Sudhindra P, Ladenheim A, Wang G, Karmen CL, Demarest V, Dupuis AP 2nd, Wong SJ. Co-infections in persons with early lyme disease, New York, USA. Emerg Infect Dis. 2019;25(4):748-52. https://doi. org/10.3201/eid2504.181509. 
8. Molloy PJ, Telford SR 3rd, Chowdri HR, Lepore TJ, Gugliotta JL, Weeks KE, Hewins ME, Goethert HK, Berardi VP. Borrelia miyamotoi disease in the Northeastern United States: a case series. Ann Intern Med. 2015;163(2):91-8. https://doi.org/10.7326/M15-0333 PMID: 26053877.

9. Chowdri HR, Gugliotta JL, Berardi VP, Goethert HK, Molloy PJ, Sterling SL, Telford SR. Borrelia miyamotoi infection presenting as human granulocytic anaplasmosis: a case report. Ann Intern Med. 2013;159(1):21-7. https:// doi.org/10.7326/0003-4819-159-1-201307020-00005 PMID: 23817701.

10. Franck M, et al. Borrelia miyamotoi: 43 cases diagnosed in France by realtime PCR in patients with persistent polymorphic signs and symptoms. Front Med. 2020. https://doi.org/10.3389/fmed.2020.00055.

11. Molloy PJ, Weeks KE, Todd B, Wormser GP. Seroreactivity to the C6 peptide in Borrelia miyamotoi infections occurring in the Northeastern United States. Clin Infect Dis. 2018;66(9):1407-10.
12. Telford SR 3rd, Goethert HK, Molloy PJ, Berardi VP, Chowdri HR, Gugliotta $J \mathrm{~L}$, Lepore TJ. Borrelia miyamotoi disease: neither lyme disease nor relapsing fever. Clin Lab Med. 2015;35(4):867-82. https://doi.org/10.1016/j. cll.2015.08.002 PMID: 26593262.

13. Cook MJ, Puri BK. Commercial test kits for detection of Lyme borreliosis: a meta-analysis of test accuracy. Int J Gen Med. 2016;18:427-40. https://doi. org/10.2147/IJGM.S122313.

\section{Publisher's Note}

Springer Nature remains neutral with regard to jurisdictional claims in published maps and institutional affiliations.
Ready to submit your research? Choose BMC and benefit from:

- fast, convenient online submission

- thorough peer review by experienced researchers in your field

- rapid publication on acceptance

- support for research data, including large and complex data types

- gold Open Access which fosters wider collaboration and increased citations

- maximum visibility for your research: over $100 \mathrm{M}$ website views per year

At BMC, research is always in progress.

Learn more biomedcentral.com/submissions 